\author{
Małgorzata Klaudia Kozłowska \\ magister, adwokat \\ Doktorantka w Zakładzie Prawa Administracyjnego \\ Wydziału Prawa, Administracji i Ekonomii \\ Uniwersytetu Wrocławskiego \\ m.kozlowska86@wp.pl
}

DOI: $10.35117 /$ A_ENG_17_01_03

\title{
Consistency and certainty of the road marking system as a subject of protection based on the offence law. Analysis of the characteristics of the offence from article 85 § 1 of offence code.
}

\begin{abstract}
Nowadays when the road infrastructure rapidly expands as well as the traffic, the correct road markings are of a vital importance in ensuring safety and efficiency of this traffic. Negligible number of road incidents caused by incorrect road markings results in treating quality and certainty of those markings as being of less importance. Thus, such an important issue is to ensure effective, criminal law protection of the legal interests which is a stable and reliable system of road markings. Polish legislator adopted as a subject of individual protection on the basis of code of offence inviolability of road signs and signals, and what stands behind it - stability and certainty of the road markings system.

Road markings; Inviolability of road marks and signals; Road infrastructure;
\end{abstract}

Keywords: Road markings; Inviolability of road marks and signals; Road infrastructure.

\section{Road marks and signals}

Road marks and signals, as shown in art. Article 7 act 1, acts express warnings, prohibitions, injunctions or information. Thus, they arrange the movement of vehicles and pedestrians along the road, specify the way they move along, as well as formulate specific warnings and information for road users. Undoubtedly, road marks and signals help to increase safety and assurance on the roads, that is why they are such an important part of the road landscape. The literature on the subject notes that "road marking including vertical signs and horizontal signs is intended to regulate and guide traffic (canalisation) and to alert and inform road users" [3]. Road markings and signals should be seen as a collection of visual information that has a significant impact on the safety of road users. Thus, the definition of the conditions for the protection of road signs, which guarantee road safety, ensuring the stability and certainty of road marking, prior to their wrong setting, destruction, damage or disposal, appear to be an extremely important issue.

Issues concerning the use of road markings, signals, warning devices or road safety devices are governed by the provisions of the Road Traffic Act [23] (hereinafter referred to as the Act), in the Decree of the Ministers for Infrastructure and Home Affairs and Administration on Signs and Road Signs (hereafter called r.z.s.d. )[17], as well as in the Regulation of the Minister of Infrastructure on detailed technical conditions for road signs and traffic safety devices and conditions for their placing on the road [16]. In contrast, the labeling powers specify the provisions of the Regulation of the Minister of Infrastructure on detailed traffic management conditions and the supervision of this management [15].

The legislator, in $\S 3$ r.z.s.d., enumerated the types of signs that may be used on the road, which should be understood as a separate lane consisting of a roadway, a roadside, a 
pavement, a pedestrian or a bicycle path, including a rail track located within this zone, intended for movement or standstill of vehicles, pedestrian traffic, animal riding or prodding (see Article 2, point 1 of the Act). This means that road markings and signals can be set and used on public roads, which are divided into national roads, provincial roads, county roads and municipal roads) as well as internal roads, including roads, car parks and squares intended for vehicular traffic, not belonging to any of the public road categories and not located in the lane of such roads. In addition, with road markings and signals traffic can be organized on individual components of the road, such as pavements or bike paths, bicycle lanes, bicycle locks or bike lanes.

On the roads there are used vertical markings in shield shapes, boards with inscriptions or symbols, which are also in the form of illuminated signs, horizontal markings in the form of lines, inscriptions and symbols placed on the road surface, the light signals transmitted by signalling devices, the signals given by the entitled people, sound or vibration signals sent by the devices placed on the road.

Road signs, so that they can fulfill their basic function as referred to in art. Article 71 in. with art. 5 of the Act, and thus arrange traffic and systematize it to ensure the safety of its participants, are divided into signs of prohibition, order, information and directions.

Importantly, a vertical road marking located on the right side of the roadway or above the roadway concerns the drivers on all lanes. However, if the vertical signs are placed above the individual lanes, the mark applies only to the drivers on the lane on which the marking is placed. On the other hand, a road sign placed on the left side of the roadway or lane is a repetition of the sign on the right unless the special provisions provide otherwise.

Moreover, the driver, and therefore the person driving the vehicle or the vehicle combination, as well as the person who runs the pedestrian column, is riding or prodding the animals individually or in the herd (see Article 2 (20) of the Act) is obliged to follow the vertical road sign placed on the yellow flashing vehicle, which cleans, repairs or modernises the road.

At the same time, it should be kept in mind that road markings expressing bans or injunctions relating to the direction of travel and signs prohibiting the entry of vehicles of specified dimensions, mass or axle loads shall not apply to the driver of a rail vehicle moving on a route determined for him.

Arguable may be the problem of how to treat inscriptions or symbols on the label underneath the road sign. Any doubts in this regard are dispelled by $\S 2$ point 4 r.z.s.d. which explains that the inscription or symbol on the road sign is an integral part of it. This is probably due to the fact that the inscriptions on the boards under the sign give traffic participants important information about the organization, in particular, may concern the validity of the sign, the exemption period determined by placard of a traffic participant or type of vehicle and may define the traffic participant, part of the road or type of vehicle, that the marking concerns or not.

\section{Proper road marking as an important element in ensuring traffic safety}

According to the annual traffic report of the Police Headquarters for 2014, the number of motor vehicles registered in Poland is steadily increasing. In 2013, on the national roads there were 25,683,575 motor vehicles (trucks, passenger cars, motorcycles) with PL symbol on registration plates. At the same time, in 2014. Police officers throughout the country received 34970 reports of road accidents in which 3202 people were killed and 42545 people were injured. In addition, in the same year police units reported 348,028 roadside collisions, which mean "an incident occurred in land traffic caused by unintentional violation of safety rules, resulting in material damage (damage of vehicle, fence, road device, luggage, etc.), or one of the participants suffered injury resulting in a violation of bodily functions or health disorders lasting less than 7 days" [9], [21]. 
Traffic accidents caused by incorrect road marking are the marginal percentage of all traffic incidents that occurred and were reported nationwide, as evidenced by the police report on road accidents in 2014. Due to poorly secured road works, faulty traffic organization and malfunctioning traffic lights there were a total of 9 road deaths without fatalities in which 10 people were injured [10]. It should be emphasized that the number of the above accidents was determined solely on the basis of the reported events, which makes it impossible to determine unequivocally what was the actual number of accidents caused by incorrect road marking. Given the above statistics must agree with the statement of Jerzy Gruszczyński that currently "road markings are not seen as an important co-factor in road accidents, despite the fact that this is a very important part of the efficiency of the road" [4]. However, given the growing number of road users and the high number of traffic accidents and collisions involving killed and injured people (among the European Union countries, Poland ranks first in terms of number of people killed in road accidents, i.e. 9.4 people killed in 100 road accidents [22]), it is important to be aware of the importance of road markings consistency and certainty. Admirable farsightedness was exhibited by legislator accepting individual protection under the Code of Misdemeanors [24] (hereinafter referred to as k.w.) the inviolability of road markings and signals and hence - the consistency and certainty of the road marking system.

Consistency and certainty of the road marking system as a subject of protection of art. $85 \$ 1$ k.w.

Art. $85 \S 1$ k.w. provides that anyone who arbitrarily sets, destroys, damages, removes, turns on or off a sign, signal, warning or security device or changes their location, obscures or makes them invisible, is a subject to the penalty of arrest, restriction of liberty or fine.

On the basis of the above-mentioned regulation, the subject matter of protection is broadly understood as security in communication. At the same time, it can be deduced from the wording of the provision that the individual subject of protection and thus the legal interest to which a lexical order is committed and which the legislature seeks to provide for special protection is the inviolability of road markings and signals and the consistency and certainty of the marking system. Tadeusz Bojarski points out that "art. $85 \mathrm{k} . \mathrm{w}$. is to prevent disturbance of the order in the places that serve the movement. On the other hand, paragraph 1 of this Article is to protect the right of communication", since "protection of marking system is important for the traffic safety, it signals a possible threat to users, it indicates the need for caution, or secures the necessary information" [1].

There is currently no definition of what is meant by the concept of consistency and certainty of the road marking system. In the common sense, certainty means "a firm belief in the existence of something or that something is in a certain way" [7], while consistency is understood to be "unchanging for a long time" [8]. The intention of the legislator is to ensure that the signs have not been placed on the movement of illegally setting or through their inclusion and that have not been unlawfully excluded from this movement, although it should be in a particular place and function, as well as to fulfill their function. Bearing in mind the function of a road marking should meet and, therefore, organize traffic and systematize it in order to ensure the safety of its participants, the concept of 1consistency and certainty of road markings should be closely associated with this function. Traffic participant, who depends on signs must be sure that adjusting to a particular marking will not bring danger for thimslef and others, or interfere with its functioning. Thus, the consistency and stability of the road marking system, in the context of art. $85 \S 1 \mathrm{k}$.w. should be understood through the prism of protection that the legislator wants to provide, which consists in the fact that the signs placed on the road in accordance with the law will visibly communicate the full information in order to organize traffic and ensure the safety of its participants. 
It should be added that the protection of the Code, covers only safety and traffic organizing equipment, which has been "set by the competent authority on the basis of traffic organization approved by the governing body movement. If a sign or other device has been set up by an authority, such as roadside property owner, or by the competent authority, but not in compliance with the approved organization of movement, does not use the protection of Art. $85 \S 1$ of the k.w." [18].

It should be clarified, the provision of Art. $85 \S 1 \mathrm{k} . \mathrm{w}$. protects not only the safety and order of communication in land traffic on each road type, "but also in water, rail, air traffic which may be threatened by even one of the perpetrators of certain behaviors at the disposal of the analyzed article" [12].

\section{Forms of offenders behavior as a subject to penalization}

Criminal offender behavior described within Article. $85 \S 1$ k.w. in a casuistic manner, because it would be difficult to describe the procedure in terms of consistancy and certainty of road marking in one general definition.Legislator introducing a closed list of delinquent behavior, penalizes operation of the perpetrator, which provide for setting (i.e. is placed in a certain way, or in a certain position), destruction (i.e. doing useless) malfunctions, removing and turning on or off of signs, signals, safety devices and warning devices.

There might be some doubts with definitions when trying to determine if road marking removal is a criminal action. Thus, if only for a lasting and irreversible removal of the safety and organizing device, we may talk about filling the marks of the substantive offense party from Article. $85 \S 1 \mathrm{k} . \mathrm{w}$., or in other cases as well? Interpretation doubts in the substantive scope blew Marcin Wojciechowski, indicating that "both the temporary removal of a particular road sign, as well as its ultimate removal (i.e. irreversible annihilation, which makes the restitution must rely on re-setting of another copy of the same kind of sign)" [14], it fulfills the statutory character of the criminal offences.

At the same time, "the legislator, in addition to the abovementioned behaviors, allows also to act in a different manner, by altering position, covering or making it invisible. For the purpose of the substantive offence, it is important that the perpetrator's conduct, the manner in which it is carried out, as set out in the content of analyzed article, make it impossible to read both the signs and the signals sent by the warning or security devices or to subordinate them." [13]. Characterization the perpetrator's actions in an alternative way does the deed described in Art. $85 \S 1$ k.w. multivarietal offence.

In order to be able to talk about the criminal offence, the action should be directed to a sign, signal, warning or security device, where "destruction and damage are directed to the marking substance or device and the other forms on their location (setting, positioning, removal, switching (on, off) or visibility (shading, invisible)" [19].

Use of a closed, specific and defined catalog of objects of violation from art. $85 \S 1$ k.w. makes it "not protected subjects are those not mentioned in the provision, for example advertising poles in the road lane" [11].

\section{A few words about the offender of art. $85 \S 1 \mathrm{k.w}$. and his criminal behavior}

The subject of the prohibited acts, and therefore its perpetrator may be in principle a legal person who incurs criminal liability. According to the Code regulations for Offenses Against the Safety and Stability of Road Marking, anyone who acts under the conditions described in Article $85 \S 1$ of the Code may do it, which is in favor of the general character of the substantive deed.

Specifying the above considerations, it should be pointed, however, that in accordance with Art. $8 \mathrm{k}$.w. the offender may only be a person who has reached the age of 17 at the date of the offense. The use of age by the legislator means that minors, and therefore those who did 
not reach the age prescribed by law at the date of the act, are not liable for the offense, since they cannot be blamed for guilt.

From the literal wording of Art. $85 \S 1 \mathrm{k} . \mathrm{w}$. it is possible to conclude that the offender can only be the legal person who reached at the time 17th birthday. Only in the margin, in the context of the comments made above, it must be pointed out that the protection of safety in communication and the stability of road marking has been extended much further than the provisions of the Code of Misdemeanors, which reaffirms the thesis on the far-sightedness of the legislature and the far-reaching need for the protection of the right to property described in discussed article. The Juvenile Justice Act [25] classifies an act prohibited by a law that is a violation of safety and road marking as a criminal offense (see Article $1 \S 2$ (2) (b) of the Juvenile Justice Act). In the case of a minor who, by reason of age, cannot be the perpetrator of the offense and is therefore subject to criminal liability laid down in the Code, i.e. a person who has been 13 years old and not reached 17 years, and who commits an offense under Art. $85 \S 1$ of the Code, the childcare and correction measures may be applied according to the provisions of the abovementioned provisions. of the Act (Article 6, paragraphs $1-11$ of the Law on the Procedure in Minorities).

In order to consider perpetrator's behavior as criminal, it must be characterized by arbitrariness, which means that the misdeed must be intentional, both in direct and potential intention. "The essence of intent is an intention to commit a forbidden act. It signifies the perpetrator's awareness and his willingness to make his / her behavior (action or omission) a manifestation of the offense" [2]. The offender of art. $85 \S 1 \mathrm{k} . \mathrm{w}$. when attempting to assassinate the right to the protection of the law, it is therefore desirable to commit a prohibited act (direct intention) or, in the case of a potential intention, not to attempt to commit it, but to provide for the possibility of committing it.

The dictionary definition of the term "lawlessness" as the act of self-will, the action contrary to the prohibitions and regulations [6] emphasizes the volitional character of the person's actions, driven by his/her will and dependent on his/her will. Thus, not every human activity described in Art. $85 \S 1$ k.w. targeted on the definition of the protected subject will be the character of a prohibited act. Unintentional behavior is not penalized, in the sense of the abovementioned provision, even when the action of the subject has led to the imminence of the offense. According to Art. $6 \S 2 \mathrm{k} . \mathrm{w}$. unintentional offense occurs when the offender does not commit it's intention, commits it, however, as a result of failure to observe safety precautions required under the circumstances, even though he/she foresaw or could have foreseen the possibility of committing this misdeed. To illustrate the discussed issue, one should use the example described by Ryszard Stefański, who points out that it will not be possible to realize the character of the act prohibited by Art. $85 \S 1 \mathrm{k} . \mathrm{w}$. in the event of a damage to the road marking due to the driver's inadvertent overturning, or if the sign or safety device is damaged by a traffic accident [20].

\section{Criminal punishment}

Unauthorized setting, destruction and damage to characters are threatened with three alternative penalties.

Extreme penalties for committing an offense under Art. $85 \S 1 \mathrm{k} . \mathrm{w}$. is a prison sentence, which is the only insolvency penalty under the Code of Misdemeanors. It depends on the deprivation of liberty of a person and can be judged in the range of 5 to 30 days. This penalty is always alternated with other penalties for the offense, and Art. $35 \mathrm{k} . \mathrm{w}$. specifies additional, special conditions of its targeting. Under the abovementioned regulation, detention may only be ordered if the offense has been committed intentionally and at the same time as the sentence of the arrest warrant shows the seriousness of the offense or the circumstances of the case show the demoralization of the perpetrator or the manner in which the offender 
deserves special condemnation. Taking into account the fact that the violation of art. $85 \S 1$ k.w. can only be committed intentionally and knowing the intention of the legislator, which broadly protects road safety and the stability and certainty of road markings, it can be assumed that the imposition of a prison sentence for committing the offense should be the most realistic sanction.

Except for the penalty of the offender, a libel penalty may be imposed on the perpetrator. The second most severe punishment for the offense against the consistency and certainty of road marking is the penalty of restriction of liberty, which is always imposed for a period of one month. It is based on the limitation of the freedoms of the penitentiary, who is subject to the code of duty mentioned above. During the execution of the sentence, the perpetrator of the offence may not, without the consent of the court, change his / her habitual residence, be obliged to carry out free, controlled work for social purposes in a suitable workplace, health service, social welfare center, charitable organization or institution, or for the benefit of the local community in the range of 20 to 40 hours and is required to provide explanations regarding the course of the sentence. The mildest of the foreseen in Art. $85 \S 1$ k.W. penalty is a fine, which is imposed in the amount of 20 to $5000 \mathrm{zl}$.

Apart from the basic penalties which may be imposed for the offense discussed by the legislator, Art. $85 \S 3$ of the Act, probably due to the essence of the act, made it possible to impose on the perpetrator a penalty measure in the form of an obligation to pay the equivalent of damaged or damaged object or obligation to restore to the previous state. Judgment by the court of the penal measure of a compensatory nature is optional, which means that the court may or may not impose additional offence on the perpetrator.

In the era of developing road infrastructure and increasing traffic volume, proper road marking is an important element to ensure traffic safety and efficiency. The insignificant number of accidents caused by inadequate road markings make the importance of the quality of their markings and the need for the stability and certainty of the road marking system to be marginalized. „The general belief about such a low impact of infrastructure on Polish roads, and in particular the underestimation of the role of road marking, is a convenient transfer of responsibility to road users and, possibly, to other - unspecified or undefined - causes. Although the quality of roads is increasingly being talked about, the issues of their marking are usually ignored. And that information is one of the most important factors that can create and protect traffic, and that information, especially the marking, is one of the essential elements of road infrastructure. "[5] It is therefore important to ensure that the legal good is still in force, which is the consistency and certainty of the road marking system and the knowledge of the rules that sanction the behavior of the person who had infringed them. Otherwise, consequences that may affect road users due to their bad marking, resulting from the criminal misconduct, destruction, damage, removal, inclusion or exclusion of the sign, signal, warning or security device, or alteration of their position, obscuring or making them invisible, can be tragic in their effects.

\section{Source materials:}

[1] Bojarski T. (red.), Kodeks wykroczeń. Komentarz, wyd. V, WK 2015, http://sip.lex.pl/\#/komentarz/587588554/474201/kodeks-wykroczen-komentarz-wyd$\mathrm{v}, 22.03 .2016 \mathrm{r}$.

[2] Budyń- Kulik M., Kodeks karny. Komentarz, (red.) Mozgawa M., wyd. VII, WK2015, http://sip.lex.pl/\#/komentarz/587231018/486669/kodeks-karny-komentarz-wyd-vii, 28.03.2016 r.

[3] Datka S., Suchorzewski W., Tracz M., Inżynieria ruchu, Warszawa, WKŁ, 1999.

[4] Gruszczyński J., Oznakowanie dróg a bezpieczeństwo ruchu drogowego, Magazyn Autostrady 12.2009, s. 28. 
[5] Gruszczyński J., Oznakowanie dróg- prawo a praktyka, Inwestycje Sektora publicznego, Lipiec 2011, s. 24.

[6] http://sjp.pl/samowolnie z dnia 28.03.2016 r.

[7] http://sjp.pwn.pl/slowniki/pewno\%C5\%9B\%C4\%87.html z dnia 15.10.2016 r.,

[8] http://sjp.pwn.pl/szukaj/stabilno\%C5\%9B\%C4\%87.html z dnia 15.10.2016 r.,

[9] http://www.brd.org.pl/2,148,Kolizja_czy_wypadek_drogowy.htm, 09.03.2016 r.

[10] Ibidem, s.35.

[11] Ibidem.

[12] Jankowski W., Kodeks wykroczeń. Komentarz, (red.) Grzegorczyk T. H., wyd. II, LEX 2013, http://sip.lex.pl/\#/komentarz/587263644/140492/kodeks-wykroczenkomentarz-wyd-ii, 28.03.2016 r.

[13] Jankowski W., Kodeks wykroczeń. Komentarz, (red.) Grzegorczyk T. H., wyd. II, LEX 2013, http://sip.lex.pl/\#/komentarz/587263644/140492/kodeks-wykroczenkomentarz-wyd-ii, 28.03.2016 r.

[14] Marcinkowski W., Glosa do wyroku Sądu Najwyższego z dnia 5 grudnia 2000 r., V KKN 432/2000, Prokurator 2002/1/79-82.

[15] Rozporządzenie Ministra Infrastruktury z dnia 23 września 2003 r.w sprawie szczegółowych warunków zarządzania ruchem na drogach oraz wykonywania nadzoru nad tym zarządzaniem (Dz.U.2003.177.1729 z dnia 2003.10.14).

[16] Rozporządzenie Ministra Infrastruktury $z$ dnia 3 lipca 2003 r.w sprawie szczegółowych warunków technicznych dla znaków i sygnałów drogowych oraz urządzeń bezpieczeństwa ruchu drogowego i warunków ich umieszczania na drogach (Dz.U.2003.220.2181 z dnia 2003.12.23)

[17] Rozporządzenie Ministrów Infrastruktury oraz Spraw Wewnętrznych i Administracji z dnia 31 lipca 2002 r.w sprawie znaków i sygnałów drogowych (Dz.U.2002.170.1393 z dnia 2002.10.12).

[18] Stefański R. A., Komentarz do niektórych przepisów Kodeksu wykroczeń, [w:] Wykroczenia drogowe. Komentarz, wyd. II, LEX 2011, http://sip.lex.pl/\#/komentarz/587233819/106950/komentarz-do-niektorych-przepisowkodeksu-wykroczen-w-wykroczenia-drogowe-komentarz-wyd-ii, 18.03.2016 r.

[19] Stefański R. A., Komentarz do niektórych przepisów Kodeksu wykroczeń, [w:] Wykroczenia drogowe. Komentarz, wyd. II, LEX 2011, http://sip.lex.pl/\#/komentarz/587233819/106950/komentarz-do-niektorych-przepisowkodeksu-wykroczen-w-wykroczenia-drogowe-komentarz-wyd-ii, 18.03.2016 r.

[20] Stefański R. A., Komentarz do niektórych przepisów Kodeksu wykroczeń, [w:] Wykroczenia drogowe. Komentarz, wyd. II, LEX 2011, http://sip.lex.pl/\#/komentarz/587233819/106950/komentarz-do-niektorych-przepisowkodeksu-wykroczen-w-wykroczenia-drogowe-komentarz-wyd-ii, 18.03.2016 r.

[21] Symon E., Wypadki drogowe w Polsce w 2014 r., Wydział Ruchu Drogowego Biura Prewencji i Ruchu Drogowego Komendy Głównej Policji, Warszawa 2015, s.5- 6.

[22] Symon E., Wypadki drogowe w Polsce w 2014 r., Wydział Ruchu Drogowego Biura Prewencji i Ruchu Drogowego Komendy Głównej Policji, Warszawa 2015, s.84.

[23] Ustawa z dnia 20 czerwca 1997 r. prawo o ruchu drogowym (Dz.U.2012.1137 z dnia 2012.10.18)

[24] Ustawa z dnia 20 maja 1971 r. kodeks wykroczeń (Dz.U.2015.1094 z dnia 2015.08.04).

[25] Ustawa z dnia 26 października 1982 r. o postępowaniu w sprawach nieletnich (Dz.U.2014.382 z dnia 2014.03.25). 